\title{
Episodic flood inundations of the northern plains of Mars
}

\author{
Alberto G. Fairén, ${ }^{\mathrm{a}, \mathrm{b}, *}$ James M. Dohm, ${ }^{\mathrm{c}}$ Victor R. Baker, ${ }^{\mathrm{c}, \mathrm{d}}$ Miguel A. de Pablo, ${ }^{\mathrm{b}, \mathrm{e}}$ Javier Ruiz ${ }^{\mathrm{f}}$ \\ Justin C. Ferris, ${ }^{\mathrm{g}}$ and Robert C. Anderson ${ }^{\mathrm{h}}$ \\ ${ }^{a}$ CBM, CSIC-Universidad Autónoma de Madrid, 28049 Cantoblanco, Madrid, Spain \\ b Seminar on Planetary Sciences, Universidad Complutense de Madrid, 28040 Madrid, Spain \\ ${ }^{c}$ Department of Hydrology and Water Resources, University of Arizona, Tucson, AZ 85721, USA \\ ${ }^{\mathrm{d}}$ Lunar and Planetary Laboratory, University of Arizona, Tucson, AZ 85721, USA \\ e ESCET, Universidad Rey Juan Carlos, 28933 Móstoles, Madrid, Spain \\ ${ }^{\mathrm{f}}$ Departamento de Geodinámica, Universidad Complutense de Madrid, 28040 Madrid, Spain \\ g US Geological Survey, Denver, CO 80225, USA \\ $\mathrm{h}$ Jet Propulsion Laboratory, Pasadena, CA 91109, USA
}

\begin{abstract}
Throughout the recorded history of Mars, liquid water has distinctly shaped its landscape, including the prominent circum-Chryse and the northwestern slope valleys outflow channel systems, and the extremely flat northern plains topography at the distal reaches of these outflow channel systems. Paleotopographic reconstructions of the Tharsis magmatic complex reveal the existence of an Europe-sized Noachian drainage basin and subsequent aquifer system in eastern Tharsis. This basin is proposed to have sourced outburst floodwaters that sculpted the outflow channels, and ponded to form various hypothesized oceans, seas, and lakes episodically through time. These floodwaters decreased in volume with time due to inadequate groundwater recharge of the Tharsis aquifer system. Martian topography, as observed from the Mars Orbiter Laser Altimeter, corresponds well to these ancient flood inundations, including the approximated shorelines that have been proposed for the northern plains. Stratigraphy, geomorphology, and topography record at least one great Noachian-Early Hesperian northern plains ocean, a Late Hesperian sea inset within the margin of the high water marks of the previous ocean, and a number of widely distributed minor lakes that may represent a reduced Late Hesperian sea, or ponded waters in the deepest reaches of the northern plains related to minor Tharsis- and Elysium-induced Amazonian flooding.
\end{abstract}

Keywords: Mars; Tharsis floods; Oceans; Lakes

\section{Introduction}

Elucidating the hydrogeological cycle of Mars is one of the main challenges in the exploration of the Solar System. Long-term aqueous activity on the surface of the planet is indicated by fluvial (e.g., Mars Channel Working Group, 1983; Malin and Edgett, 2000a, 2000b) and lacustrine features (e.g., Squyres, 1989; Scott et al., 1995; Cabrol and Grin, 1999, 2001); phased degradation of impact craters (e.g., Chapman and Jones, 1977; Craddock and Maxwell, 1993); permafrost (e.g., Lucchitta, 1981); periglacial (e.g., Squyres, 1979) and glacial landforms (e.g., Lucchitta, 1982; Kargel et al., 1995); and outflow channels (e.g., Baker and
Milton, 1974; Scott and Tanaka, 1986; Greeley and Guest, 1987). The outflow channels began to form as early as the Noachian, and their activity extended to the Early Amazonian (Rotto and Tanaka, 1991a; Dohm et al., 2001a), and even to the latest Amazonian in Elysium Planitia (Berman and Hartmann, 2002; Burr et al., 2002a, 2002b), with recurrent flooding for some of the systems, including Kasei Valles (Scott, 1993) and Mangala Valles (Chapman and Tanaka, 1993).

Diverse geologic and geochemical evidence collectively point towards the previous existence of wide oceans over the Martian northern lowlands, which include: (1) the Martian dichotomy boundary, which separates the southern highlands from northern lowlands (e.g., Tanaka et al., 1992; Smith and Zuber, 1996), and provides a topographically lower area in the plains for water accumulation; (2) the 
outflow channels, which either terminate at the boundary (Parker et al., 1993) or fade into the northern plains (Ivanov and Head, 2001), including the prominent circum-Chryse (e.g., Rotto and Tanaka, 1995) and recently identified northwestern slope valleys (NSVs, Dohm et al., 2000, 2001a) outflow channel systems; (3) the relatively low density of superposed impact craters in the northern plains compared to the southern densely cratered highlands (Barlow and Bradley, 1990; Parker et al., 1993), and its extremely flat topography at the distal reaches of the outflow channel systems (Head et al., 1999); (4) the broad occurrence of wide age-ranging glaciers that are interpreted to be linked to magmatic-triggered flooding and associated short-lived (tens of thousands of years) environmental/climatic changes (Baker, 2001; Cabrol et al., 2001a, 2001b, 2001c); and (5) the chemical signatures reported for the northern plains, including high abundances of $\mathrm{S}$ and $\mathrm{Cl}$ or the possible existence of sulphate minerals and chloride salts, making a putative andesite-rich component or weathered basalt the dominant material type in the lowlands (McSween et al., 1999; Zuber, 2001; Wyatt and McSween, 2002). Standing bodies of water, therefore, best explain such evidence, though volcanism (Head et al., 2002), tectonism (Sleep, 1994), eolian modification (Malin and Edgett, 2000a), ground volatile and debris flow activity along the highland-lowland boundary (Tanaka, 1997; Tanaka et al., 2002), and/or glacial processes (Baker et al., 1991) also probably contributed to shaping the Martian lowlands.

The presence of large bodies of water during different periods of time on the northern lowlands of Mars have been previously proposed (McGill, 1985; Jöns, 1986; Lucchitta et al., 1986; Parker et al., 1987, 1989, 1993; Baker et al., 1991; Scott et al., 1991a, 1991b; Chapman, 1994; Scott et al., 1995; Scott and Chapman, 1995; Kargel et al., 1995; Head et al., 1999). For example, Parker et al. $(1987,1989)$ described seven different boundaries, but only two of them could be approximately traced as complete closures within and on the margins of the northern lowlands. Parker et al. (1993) proposed an outer boundary, or Contact 1, located along the Martian dichotomy, as the high water mark of a primitive ocean. The later second enclosured boundary, or Contact 2, which occurs several hundreds of kilometers north of the dichotomy, is less extensive, and would indicate a younger high-stand water mark (see Clifford and Parker, 2001, for a complete discussion about the contacts). A subsequent analysis by Head et al. (1999) pointed out that Contact 2 could represent the only possible shoreline, because the variations of the elevation in Contact 1 do not reflect an equipotential surface. In addition, Scott et al. (1995) present geologic and geomorphic evidence for the possible existence of mid-sized lakes in the deeper reaches of the lowlands as recent as the Amazonian Period, though they also indicate that a larger water body may have existed if the lakes had been earlier connected at a similar elevation.

Supported by published geologic, geomorphic, paleohydrologic, and topographic information, and in conjunction
Table 1

Absolute age estimates for the surface of Mars

\begin{tabular}{lc}
\hline Epoch & Absolute age range $(\mathrm{Ga})$ \\
\hline Late Amazonian & $0.6-0.3$ to present \\
Middle Amazonian & $2.1-1.4$ to $0.6-0.3$ \\
Early Amazonian & $3.1-2.9$ to $2.1-1.4$ \\
Late Hesperian & 3.6 to $3.1-2.9$ \\
Early Hesperian & 3.7 to 3.6 \\
Late Noachian & 3.82 to 3.7 \\
Middle Noachian & 3.95 to 3.82 \\
Early Noachian & $>3.95$ \\
\hline
\end{tabular}

Condensed from Fig. 14 of Hartmann and Neukum, 2001.

with the MEGAOUTFLO hypothesis that explains episodic water stability in the lowlands of Mars (Baker et al., 1991, 2000; Baker, 1999), we propose a conceptual model here that points out the direct impact of Tharsis-triggered flood inundations in the shaping of the northern lowlands (Fig. 1). An enormous Noachian basin/aquifer system in eastern Tharsis has been revealed by paleotopographic reconstructions of the Tharsis magmatic complex in the western hemisphere of Mars, proposed to have sourced the Tharsis-triggered outburst floods that sculpted the circum-Chryse and NSVs outflow channel systems (Dohm et al., 2001b), entrained boulders, rock, and sediment during passage, and ponded to form sequentially through time various hypothesized oceans, seas, and lakes (e.g., McGill, 1985; Jöns, 1986; Parker et al., 1987, 1993; Baker et al., 1991; Scott et al., 1995; Head et al., 1999) (Fig. 2). The dwindling of these floodwaters through time, due to an inadequate recharge of the Noachian drainage basin/aquifer system, is expected during the time of noted low erosion rates following the late heavy bombardment. Note that we use inferred absolute ages recently condensed from models of impactor populations and studies of martian meteorites (Hartmann and Neukum, 2001; see Table 1).

\section{Physiographic setting}

The northern and southern provinces represent a physiographic and geomorphologic dichotomy of the martian crust. The boundary clearly separates relatively young, uncratered surface materials of the lowlands from the highly cratered, ancient highland rock assemblages. The lowland materials are interpreted to have been emplaced by both subaerial and subaqueous processes, which include eolian, volcanic, fluvial, mass-wasting, lacustrine, and marine (e.g., Scott and Tanaka, 1986; Tanaka, 1986; Greeley and Guest, 1987; Parker et al., 1993; Scott et al., 1995; Tanaka et al., 2002). The ancient highlands consist of a mélange of rocks that are interpreted to mainly include lava flows, impact breccias, and eolian, fluvial, and colluvial deposits (e.g., Scott and Tanaka, 1986; Tanaka, 1986; Greeley and Guest, 1987; Dohm and Tanaka, 1999), although glacial deposits have also been proposed (e.g., Kargel and Strom, 1992; Kargel et al., 1995). 


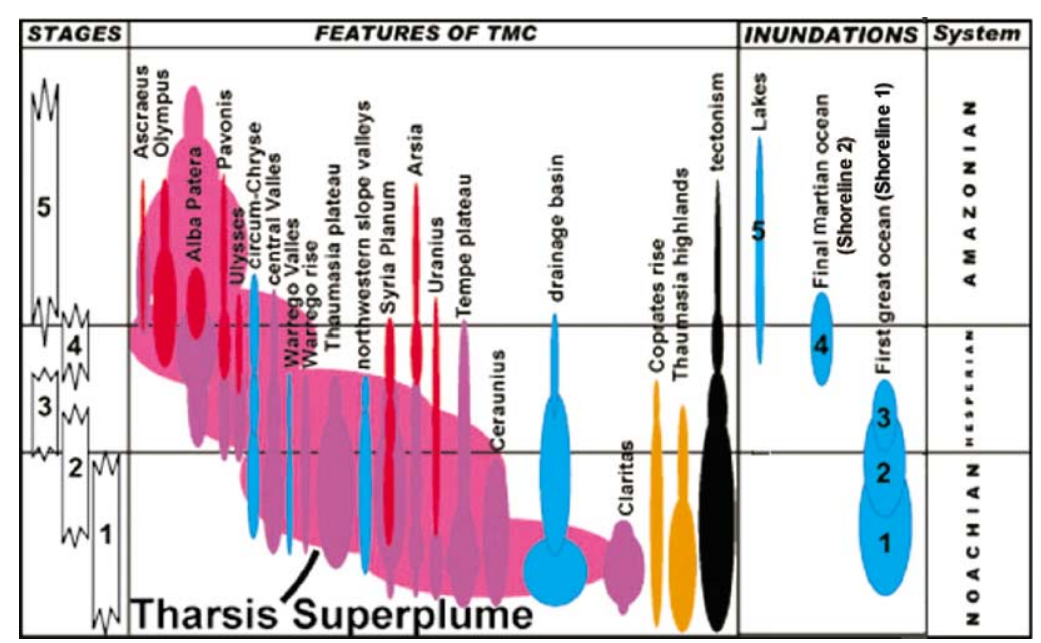

Fig. 1. Chart comparing the evolutional stages of geologic activity in the Tharsis Magmatic Complex/superplume region with major geologic features and proposed inundations (Stage information corresponds to Stage information of Fig. 2); size of solid areas roughly proportional to degree of exposed deformation and feature extent. Violet-centers of tectonic activity interpreted to be the result of magmatic-driven uplift and local volcanism, dike emplacement, and hydrothermal activity; orange—mountain building; blue—water; red-primarily emplacement of shield-forming and lava-field-forming lavas. Note that the commencement and/or end of activity of the components of the complex and inundations are not absolutely constrained and that features such as the shield volcanoes of Tharsis Montes and Olympus Mons could be presently active. The schematically portrayed events are those that have survived thousands and perhaps millions of years of wind and water erosion to stand out as significant windows of the Martian past, while smaller windows have been erased or highly subdued from the Martian record; the inundation representations, for example, may include several isolated events.

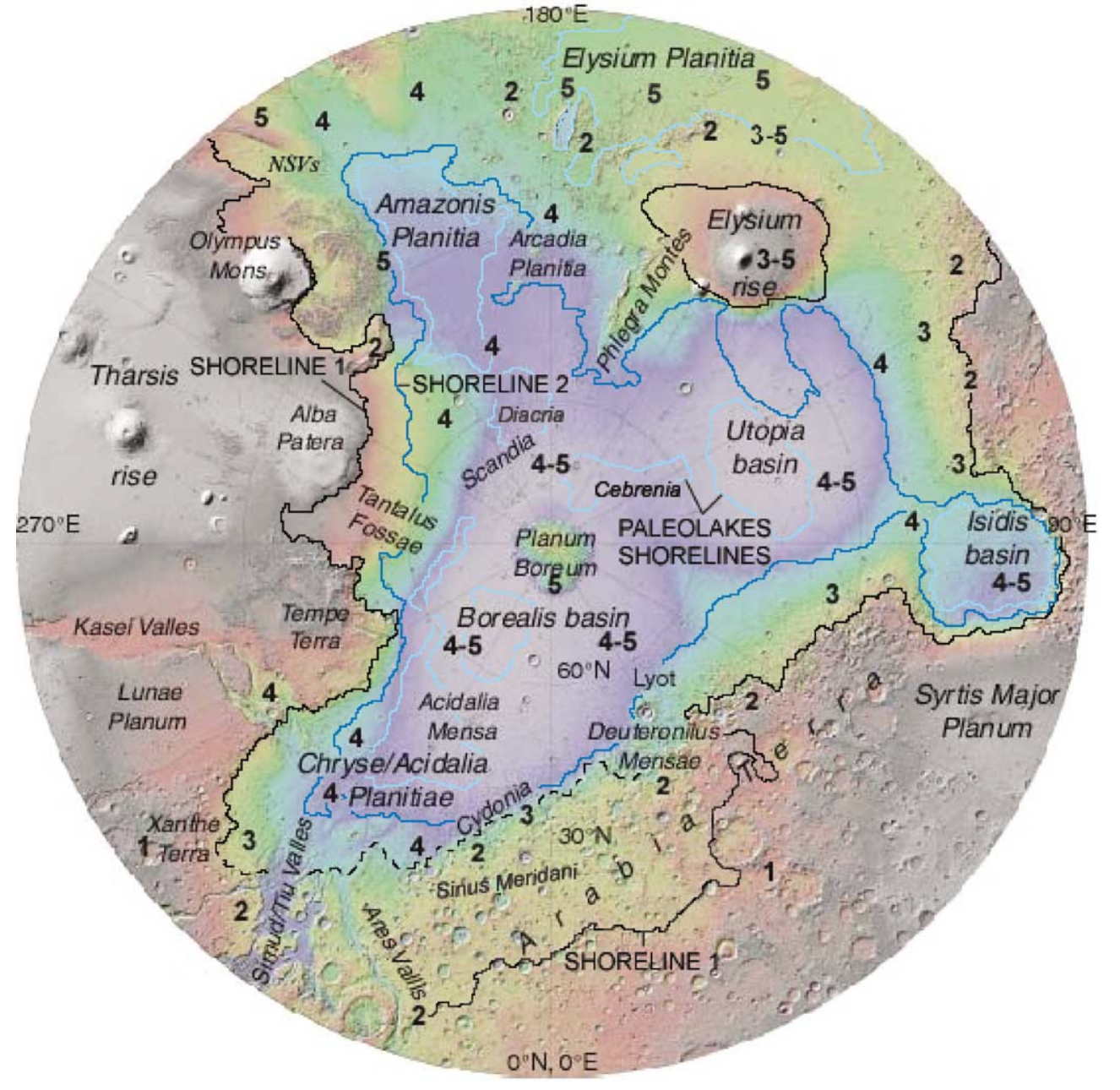

Fig. 2. Topographic shaded relief map of the northern hemisphere of Mars constructed from Mars Orbiter Laser Altimeter (MOLA) data showing major geographic features of the northern hemisphere, including three major basins (Borealis basin = Vastitas Borealis, Utopia basin = Utopia Planitia, Isidis basin = Isidis Planitia). Also shown are Shoreline 1 (black line), Contact 1 in Arabia Terra (dashed-black line) and Shoreline 2 (dark blue line), which are based on Edgett and Parker (1997), Carr (2002), Parker et al. (1987, 1989, 1993), Clifford and Parker (2001), and Head et al. (1999); paleolakes (light blue lines), based on Scott et al. (1995); and Stage information (numbers) that reflects the geologic mapping of Tanaka et al. (2002) and correlative with Stage information of Dohm et al. (2001b, 2001c) and Anderson et al. (2001). Polar Stereographic projection; scale varies with latitude; modified from Tanaka et al. (2002). 
The origin of the generally smooth plains-forming Martian northern lowlands, the locality where Tharsis-triggered floodwaters may have ponded to form the putative oceans and small water bodies, remains uncertain. However, it has been proposed that the Martian highland/lowland boundary began to form at least since the Noachian (Dohm et al., 2001b). Several hypotheses have been invoked for its origin, which include either subcrustal erosion resulting from mantle convection (Wise et al., 1979), excavation by one or more large impacts (Wilhelms and Squyres, 1984; Frey et al., 2002), or overturn of unstable cumulates in an initial magma ocean (Hess and Parmentier, 2001). Alternately, the landscape of the northern lowlands may have been the result of sea-floor spreading, linked to plate tectonism (Sleep, 1994), during the Early into Middle Noachian (Baker et al., 2002; Dohm et al., 2002; Fairén et al., 2002). In fact, although lowlands' basement is old, perhaps dating from the final Early Noachian (Frey et al., 2002), the cratered highlands (except for the northwestern part of Arabia Terra; an area noted by Zuber et al. (2000) to be related to the lowlands due to its relatively thin crust) are older indeed (Frey, 2003). Thus, some hundreds of millions of years during the embryonic stages of Mars' development may have allowed for inner processes to shape the lowlands.

Of the two shorelines proposed for the northern plains (Parker et al., 1987, 1993), the inner younger one is close to an equipotential line (Contact 2, hereafter referred as Shoreline 2), whereas the outer older shoreline (Contact 1) deviates from equipotentiallity (Head et al., 1999). Here, we suggest the existence of a greater shoreline (referred to as Shoreline1 from the previously reported position by Parker et al., 1987, 1993), which may represent the high stand of the primitive Martian ocean (Figs. 2 and 3). In western Arabia Terra, the coastline may have been some thousands of $\mathrm{km}$ upwards in the cratered terrain, which includes regions such as northern Sinus Meridiani and western Arabia Terra (Edgett and Parker, 1997). Elevation variations (equipotentiallity) decrease from $\sim 11 \mathrm{~km}$ using the previously mapped Contact 1 (Head et al., 1999) to only $\sim 2.5-3 \mathrm{~km}$ in Shoreline 1, which transects across northern Sinus Meridiani, western Arabia Terra, northeast Arabia Terra, and north Thyrrena (Tharsis and Elysium rises are not taken into account due to the abundant post-Noachian activity those structures have experienced). In addition, valley networks formed during the Noachian in Arabia Terra surround and empty at Shoreline 1; and there are only isolated valleys between Shoreline 1 and the previous position of Contact 1 in northeast Arabia (Carr, 2002; see Fig. 3B). Moreover, Shoreline 1 corresponds to the crustal thickness dichotomy, as deduced from topography and gravity data (Zuber et al., 2000; see Fig. 3C).

The volumetric extent of the earliest and largest estimated water body, in our opinion, can be best portrayed by Shoreline 1 through several lines of evidence, including:

(1) MOLA data, which shows rougher surfaces above Contact 1, less rougher surfaces at all scales between Contact 1 and Shoreline 2, and generally smooth surfaces below
Shoreline 2 (Head et al., 1999). (Note that Shoreline 1 encloses the previously mapped Contact 1; see Fig. 2).

(2) Total water capacity below Shoreline 1 (estimated to be more than $10^{8} \mathrm{~km}^{3}$ compared to the approximated capacity below the previously mapped Contact 1 of $9.6 \times 10^{7} \mathrm{~km}^{3}$ by Head et al., 1999), which lies between the minimum value for water that flowed through the Chryse outflow channels $\left(0.6 \times 10^{7} \mathrm{~km}^{3}\right.$; Carr, 1996a) and the maximum water capacity estimated for regolith ( 5 to $20 \times 10^{7} \mathrm{~km}^{3}$; Squyres et al., 1992).

(3) The newly identified Noachian-Early Hesperian NSVs outflow channel system, with an enormous estimated maximum peak discharge rate of about $2 \times 10^{10} \mathrm{~m}^{3} / \mathrm{s}$, which is proposed to be a significant source of water for the larger (Shoreline 1) ocean (Dohm et al., 2001a) (Fig. 2).

Nevertheless, magmatism and tectonism among other contributors likely modified ancient (e.g., Noachian) topography, including Shoreline 1, where a deviation of about 2-3 km from an equipotential line most likely occurred. Specifically, these deviations from equipotentiallity may be explained by:

(1) The influx of water throughout time (Cabrol and Grin, 2001).

(2) Local variations of the thermal structure of the lithosphere (due to variations in mantle heat flow or crustal heat generation, for example) that generate elevation differences between regions (Lachenbruch and Morgan, 1990; Turcotte et al., 2002; Ruiz et al., 2003). If there were regional differences in heat flow in early Mars, the subsequent progressive decline of heat flow through time might have caused differential thermal subsidence (relaxation) of the planet's lithosphere. This could have contributed to the distortion of the original Noachian topography in an even kilometric scale, including the equipotentiallity of Shoreline 1 (Ruiz et al., 2003). The original topography along Shoreline 2 is expected to be less deformed when compared to the older Shoreline 1 because mantle temperature is expected to be less through time (e.g., Schubert et al., 1992). This smaller heat flow following the Late Hesperian (smaller differences in heat flow or crustal heat production) would include a decrease in magmatic-driven uplifts and subsidence. Exceptions include Elysium rise and Alba Patera where significant, concentrated magmatic-driven activity is noted for the Late Hesperian and Amazonian (e.g., Scott and Tanaka, 1986; Greeley and Guest, 1987; Anderson et al., 2001).

(3) Pre-oceanic tectonic structural fabrics, such as structurally controlled cliffs in the hypothesized oldest and largest ocean and post tectonically-controlled elevation adjustments to putative Shoreline 1, related to the evolution of Tharsis and/or other elevational adjustments associated with local volcanism, wind and/or glacial activity, groundwater discharge and surface runoff, and tectonism (including faulting and impact cratering).

(4) A possible Early into Middle Noachian martian plate tectonism episode, with convergent plate margins and accretion of terranes (e.g., northwards Terra Cimmeria and Terra 


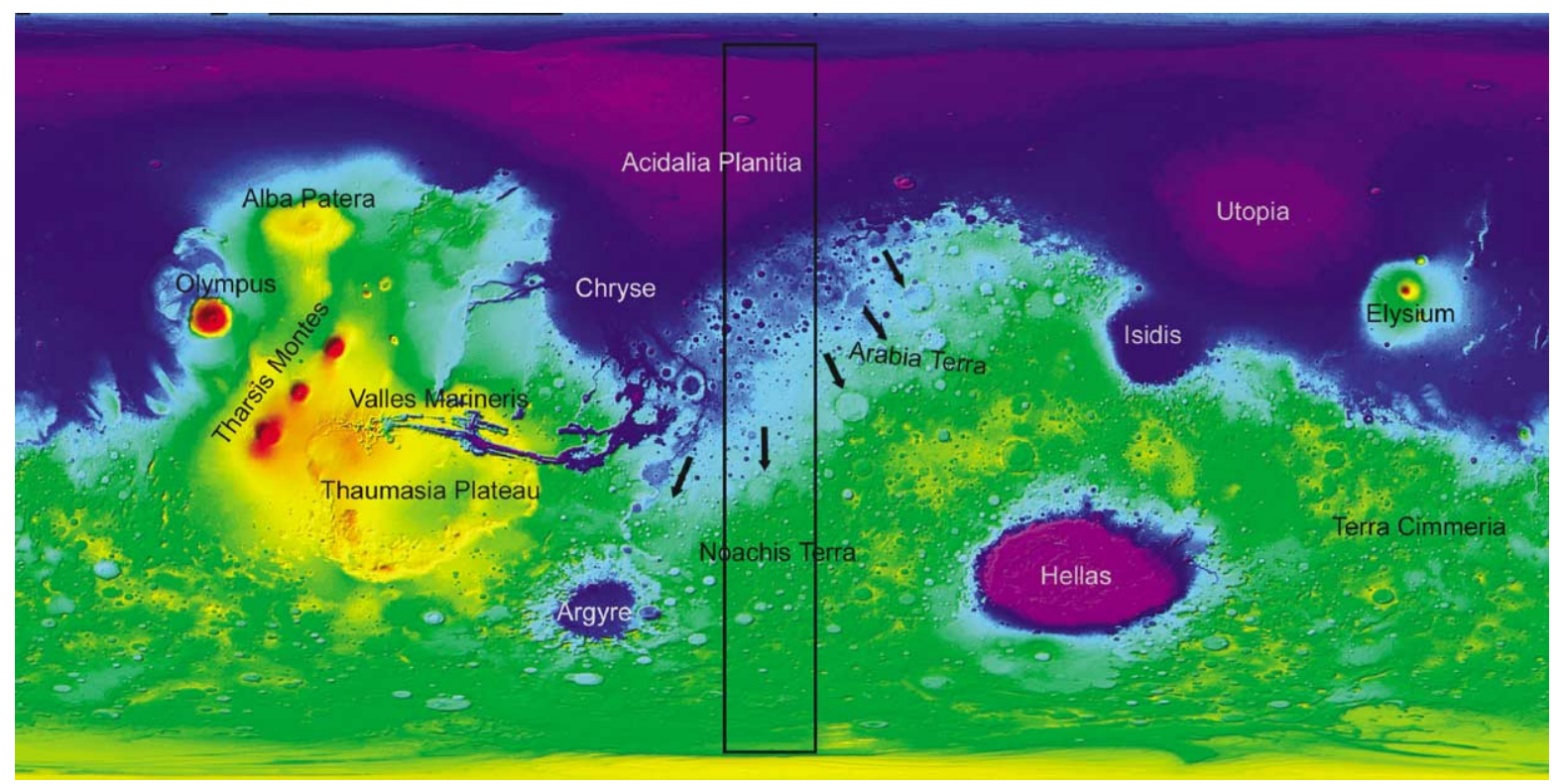

(A)

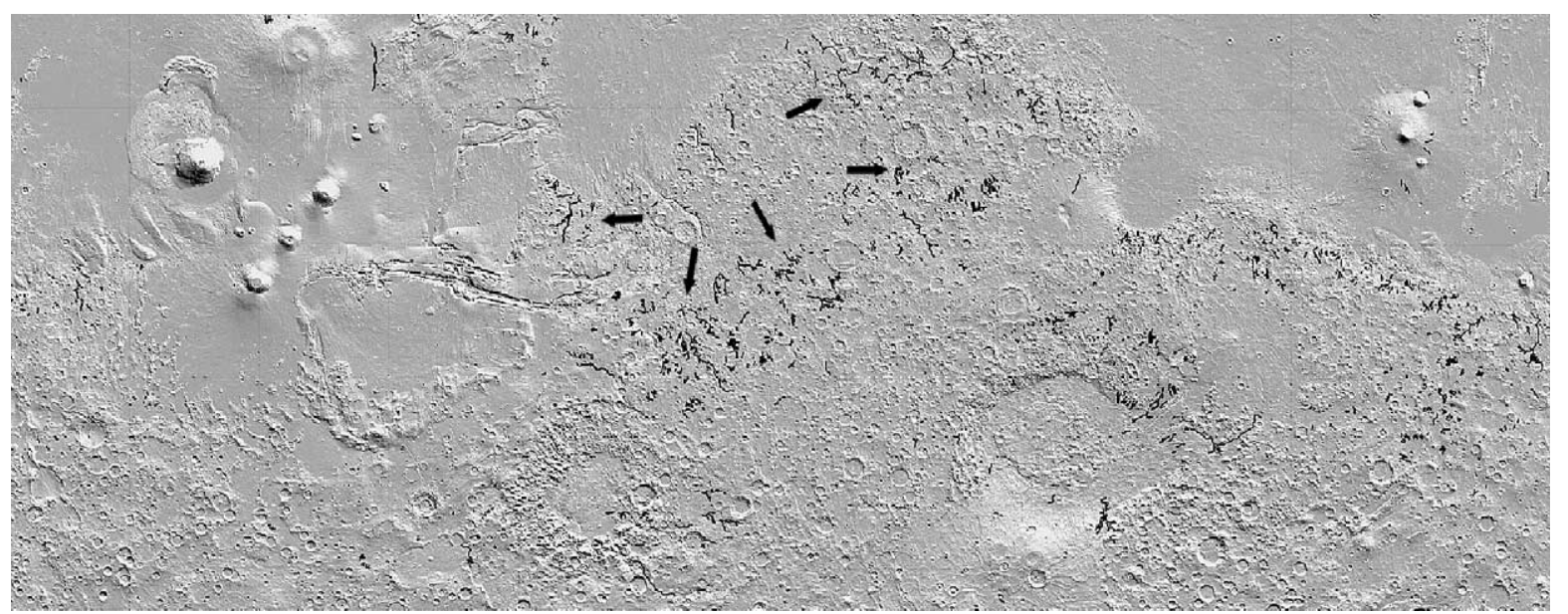

(B)

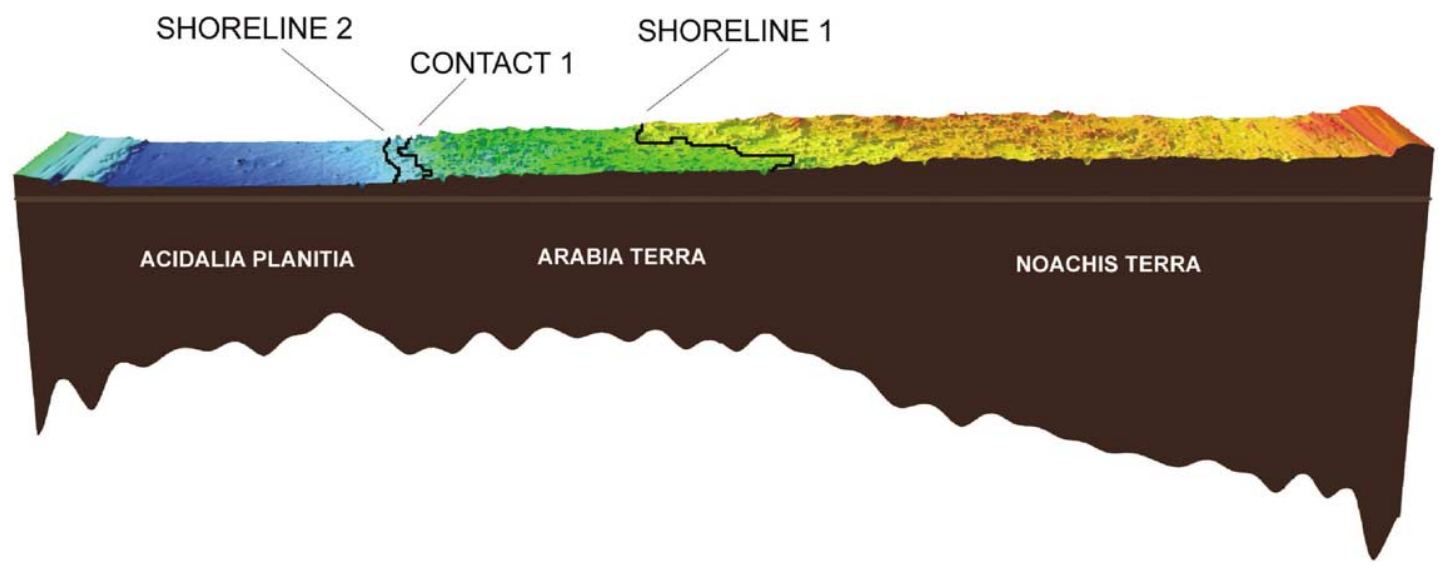

(C)

Fig. 3. A: Topographic map of Mars. Note the equipotentiallity of Shoreline 1 in northern Sinus Meridiani and western Arabia Terra. Arrows indicate the possible Noachian coastline, both in (A) and (B). Marked is the area showed in detail in (C) (IEG0062T.IMG MOLA image, both shaded and colored according to topography. Produced by Tayfun Oner). B: Valley channels appear to debouch along Shoreline 1, even in northeast and southwest Arabia Terra. (In Carr, 2002.) (C) Inferred crustal thickness from MOLA data, running from the north pole (left) to the south pole (right), along the $0^{\circ}$ longitude region, including Arabia Terra. Crustal thickness does not correlate with the dichotomy boundary or Contact 1, but appears to be related with Shoreline 1 . This could represent the first great ocean that occupied the northern plains of Mars. (Image from MOLA Science Team). 
Sirenum; Fairén et al., 2002). The proposed plate tectonism for early Mars (first hundreds of millions of years, Baker et al., 2002) would greatly modify the topography along Shoreline 1.

(5) The approximated values of the hypothesized secondary and smaller water-masses, whose associated sedimentary deposits and water resources could have altered the primitive geomorphological features of Shoreline 1.

\section{Inundation model}

In our model, the Tharsis Magmatic Complex (TMC)/Superplume development, which includes pulses of magmaticdriven hydrological activity, directly influences the evolution of the atmosphere and climate, as well as subsurface and surface water processes as observed in geologic and paleohydrologic records. Figure 1 reflects Stage information after Anderson et al. (2001) and Dohm et al. (2001b, 2001c). This model highlights Tharsis-triggered flood inundations and their direct impact on shaping the northern plains (see Fig. 2), and other contributors such as magmatic-driven activity at Elysium rise (Tanaka, 1986; Greeley and Guest, 1987; Skinner and Tanaka, 2001).

\subsection{Noachian to Early Hesperian (Stages 1-3): the first great ocean}

Incipient development of the Tharsis magmatic complex (TMC) during the Early into Middle Noachian (Anderson et al., 2001; Dohm et al., 2001b) to as late as possibly the Early Hesperian (Stages 1-3 of Dohm et al., 2001b) (Fig. 1) resulted in the first inundation; an ocean that would have covered the northern plains (approximately $1 / 3$ of the total surface area of Mars, see location of Shoreline 1 on Figs. 2 and 3). Dohm et al. (2001b) show evidence that collectively indicate that the TMC began to form sometime around Early into Middle Noachian with significant pulses of magmaticdriven activity during Stages 1-3, including the growth Arsia, Syria Planum, and central Valles Marineris rises, which are interpreted to be centers of magmatic-driven tectonism, volcanism, dike emplacement, local hydrothermal activity, and associated NSVs and circum-Chryse outflow channel activity. The development of Thaumasia plateau and the emplacement of intercrater materials, which are interpreted to be the result of phreatomagmatic explosions such as in the Valles Marineris region where magma/water/water-ice interactions have been proposed (Chapman et al., 1991), and older wrinkle ridged materials interpreted to represent deformed lava plains (Dohm et al., 2001c), may have also been influential on outflow channel activity, and related flood inundations during Stages 1-3 (Dohm et al., 2001a, 2001b, 2001c). In addition, valley networks are mainly Noachian in age (e.g., Carr, 2002), and so excellent candidates to contribute to the filling of the first great martian ocean.
The incipient development of TMC's Stage 1 may have occurred from Early into Middle Noachian. Furthermore, a magnetic field may have been operative on Mars in the initial Early into Middle Noachian (from approximately 4.4 to $4.0 \mathrm{Gyr}$ ), since one of the oldest and most dominant Noachian centres of activity, Claritas rise (Anderson et al., 2001), spatially corresponds with a magnetic anomally (Acuña et al., 1999, 2001), but not subsequent to the Hellas impact event, since the Hellas basin does not record magnetic anomalies (Acuña et al., 1999). Importantly, it is difficult to determine for sure whether the Claritas rise records incipient TMC development or whether it may be related to magmatic activity independent from TMC. In addition, plate tectonism may have been in operation during the Early into Middle Noachian, surviving the inner dynamo for some tens of millions of years (Fairén et al., 2002). If at least the first pulse of TMC magmatism accompanied plate tectonism, then the northern lowlands' landscape could have resulted from seafloor spreading (lasting from about 4.4-4.3 to approximately 3.9 Gyr; Baker et al., 2002; Dohm et al., 2002); and possible carbonate recycling would have accounted for the reinjection of large amounts of $\mathrm{CO}_{2}$ into the atmosphere. Subducted hydrous material of the lithosphere would have represented an ample supply of water for later Tharsis volcanism, and its water release to seas and/or lakes (Baker et al., 2002). In addition, Mars may have been more volatile-enriched than Earth, especially during its embryonic stages of development (Craddock and Howard, 2002). Therefore, until at least Middle Noachian, the Martian atmosphere could have been much thicker than at present, capable of sustaining a considerable and longstanding liquid ocean. As stated before, this primitive ocean is best portrayed by Shoreline 1 .

Without the magnetic field protection since the Middle to Late Noachian (Stage 2), the atmospheric erosion rate would have increased, as well as the loss of water to hydrodynamic escape. Surface water stability, however, could have been possible during hundreds of million of years (Lundin, 2001), especially if local remanent magnetic anomalies survived in the crust once the inner dynamo shut off (Jakosky and Phillips, 2001). Additionally, if Mars passed through a plate tectonic phase, its termination would have contributed to a break-up of the atmospheric equilibrium between adding and retiring carbonates; the result would be thinner, dryer and colder atmospheric conditions. The ocean would thus have been reduced and ice-covered during Late Noachian (Parker et al., 1993), and its possible geomorphologic-associated features would be erased by subsequent major hydrous cycles.

An Early Hesperian pulse of Tharsis activity (Stage 3), which includes further development of the Arsia, Syria Planum, central Valles Marineris rises, and Thaumasia plateau, may have triggered more flood waters to the northern plains adding to the potentially already existing northern plains ocean and/or ice body/ground ice. As the new floodwaters washed over the northern plains, the additional heat 
may have melted the upper layers of ice and the subsequent gradients would allow the melt water to cycle into the hydrologic system (Dohm et al., 2001a). This third major pulse of TMC activity may have contributed enough $\mathrm{CO}_{2}$ and other volatiles to the atmosphere to induce a short-lived (approximately tens of thousands of years; Baker et al., 1991, 2002) climatic perturbation. Another potential contributor to the flood inundation hypothesis during the Early Hesperian is incipient development of the Elysium rise (Tanaka, 1986; Greeley and Guest, 1987; Skinner and Tanaka, 2001; Tanaka et al., 2002). If both Tharsis and Elysium were concurrently active during the Early Hesperian, then significant climatic responses would be expected, including growth of ice sheets at the poles (Baker et al., 1991; Head and Pratt, 2001), outflow events of enormous magnitudes to the northern plains (e.g., Nelson and Greeley, 1999; Dohm et al., 2001a), and spring-fed discharge along an unvegetated (instable) highland-lowland boundary (e.g., Tanaka et al., 2002).

When compared to today's conditions, water and gases released during such Tharsis Superplume activity could have resulted in thicker post-heavy-bombardment atmospheric conditions. The first inundation originated from a highly productive aquifer system, and may have occurred when environmental conditions were more clement; the oceanic environment of the initial Oceanus Borealis may have persisted from the Early to Middle Noachian into the Early Hesperian, related to episodic, pulsating Tharsis superplume activity. For example, an amount of $\sim 3 \times 10^{8} \mathrm{~km}^{3}$ of magmas has been proposed as the total release of the Tharsis rise during the Noachian, and their volatile content would have produced the equivalent of 1.5-bar $\mathrm{CO}_{2}$ and a global layer of water of $120 \mathrm{~m}$ thickness (Phillips et al., 2001). Water could so have extended over the lowlands during hundreds of millions of years (e.g., Clifford and Parker, 2001).

\subsection{Late Hesperian/Early Amazonian (Stage 4): the last Martian ocean}

Between the disappearance of the Noachian-Early Hesperian great ocean and the temporary establishment of the Late Hesperian minor sea, a cold and dry Late Hesperian intermediate period occurred, perhaps related to a transient pause of the Tharsis development (Dohm et al., 2001b). The first clear discontinuity in TMC development is observed between stages 3 and 4, when Thaumasia Plateau was definitively established (see Fig. 1). The transition to this colder climate, and the decline in crustal heat flow, caused the freezing of the primordial ocean, which presumably developed an ice cover that thickened with both time and increasing latitude (Clifford and Parker, 2001). In addition, the colder and dryer conditions might account for the significant decline in the rate of valley network formation in the Hesperian and Amazonian (Fig. 4).

Following the period of magmatic quiescence, a major pulse of Late Hesperian/Early Amazonian TMC's ac-

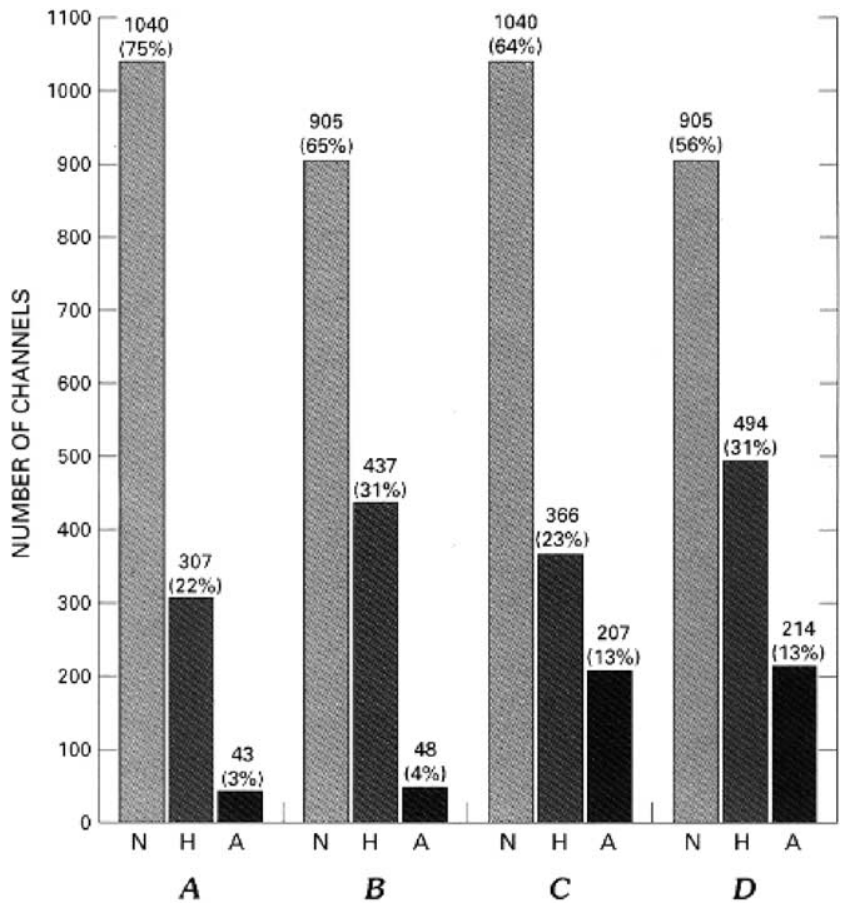

Fig. 4. Histogram showing relative ages of channels on Mars. A: Maximum stratigraphic ages of highland channels. B: Revised ages of A based on morphology. C: Maximum stratigraphic ages of highland and lowland channels. $D$ : revised ages of $\mathrm{C}$ based on morphology. $\mathrm{N}=$ Noachian; $\mathrm{H}=$ Hesperian; A = Amazonian. (From Scott et al., 1995).

tivity (Stage 4) coincides with significant outflow channel development (e.g., Scott et al., 1995; Head, 2002) and the time proposed for Shoreline 2 formation (Clifford and Parker, 2001). This new pulse triggered yet more floodwaters that incised Chryse and other circum-Chryse outflow channels (e.g., Milton, 1974; Baker and Milton, 1974; Scott and Tanaka, 1986; DeHon, 1992; DeHon and Pani, 1992; Scott, 1993; Rotto and Tanaka, 1995; Scott et al., 1995; Rice and DeHon, 1996; Chapman and Tanaka, 1996; Nelson and Greeley, 1999) and Mangala Valles (Scott and Tanaka, 1986; Chapman and Tanaka, 1993; Zimbelman et al., 1994; Craddock and Greeley, 1994; Scott et al., 1995) and ponded in the northern plains to form a sea in the deeper recesses in the lowlands (Shoreline 2), inset within Shoreline 1 (Figs. 2 and 3). In its later stages, it is also possible that this hemispheric ocean turned into a mud ocean (Tanaka and Banerdt, 2000) or froze (Carr, 1996b), or progressively diminished into small seas or lakes (Scott et al., 1995), none of these scenarios mutually exclusive. The water, $\mathrm{CO}_{2}$, and other volatiles released during this stage of significant Tharsisrelated effusive volcanic activity may have produced a transient greenhouse atmosphere.

In addition, if plate tectonism occurred, its standstill sometime in the Middle Noachian would lead to a subsequent stagnant-lid convection with mantle upwelling plumes affecting to more concrete locations under the Martian crust, because plate movement ceased. Thus, significant volcanic activity could be anticipated in these locations, as is the case 
for both Tharsis and Elysium; such Late Hesperian and Early Amazonian activity is recorded in the early development of the giant shield volcanoes, Olympus Mons, Alba Patera and the Tharsis Montes during Stage 4 of TMC development (Dohm et al., 2001b), as well as the shield volcanoes of the Elysium rise (Greeley and Guest, 1987).

\subsection{Amazonian (Stage 5): temporary lacustrine environments}

Finally, generally cold and dry desert conditions during the Amazonian were punctuated by small outflow releases such as at and near Kasei and Mangala Valles and the channels systems that debouch into Utopia basin from the northwestern flank of Elysium rise, Hrad, Apsus, Tinjar, and Granicus Valles (Greeley and Guest, 1987; Skinner and Tanaka, 2001) to form a number of minor transient seas or lakes (Fig. 2). Various isolated pulses of Tharsis magmatism are documented for the Amazonian Period (e.g., Scott and Tanaka, 1986; Greeley and Guest, 1987; Anderson et al., 2001), including the continuous growth of Olympus Mons, Alba Patera and the Tharsis Montes shield volcanoes (see Fig. 1). Late-stage Elysium Mons activity during the Amazonian (Skinner and Tanaka, 2001; Pounders et al., 2002) also may have contributed to release carbonates and water into atmosphere. In any case, the warm periods were infrequent and short $\left(10^{3}\right.$ to $10^{5}$ years $)$ as recorded in the low cumulative rates of erosion since the end of the Noachian (Baker, 1999, 2001; Carr, 2002).

High heat flux originating in magmatic activities near the surface is proposed to be responsible for the melting of $\mathrm{CO}_{2}$ clathrate, causing rapid outflows of water and so the formation of chaotic terrains (Komatsu et al., 2000); the mobilized water-sediment mixture would create outflow channels, with ages ranging from Noachian to Amazonian. Equally, melting of ground and surface ice by volcanic activity has been argued for the origin of the channels (e.g., Baker et al., 1991), the melting possibly being accompanied by hydrothermal circulation (Gulick, 1998). In fact, it is possible that substantial remnants of the floodwaters that inundated the northern lowlands during Noachian and Hesperian could remain beneath thin mantles of dust and volcanics emplaced in the Hesperian and Amazonian, as potentially indicated from the latest results of the Odyssey mission (Boynton et al., 2002).

Nevertheless, the long-term decline in planetary heat flow and sequestering $\mathrm{CO}_{2}$ in carbonates and the progressive trapping of $\mathrm{H}_{2} \mathrm{O}$ into clays in the cryosphere (Carr, 2002) would have greatly depleted the original inventory of groundwater. This could well explain the apparent decline in outflow channel activity observed during the Amazonian (Scott et al., 1995). Floods and water bodies are also expected to be progressively smaller with time due to a dwindling Noachian water supply (e.g., Noachian eastern Tharsis basin/aquifer system) and the related insufficient recharge after each endogenically-driven hydrologic event (Dohm et al., 2001b). So, the Late Hesperian-Amazonian extremely cold and dry conditions could even include the presence of a mantled, thin frozen ocean in the deeper reaches of the northern plains (Janhunen, 2002).

In addition, the environmental conditions between each period ensures the loss of water from the global inventory. The comparatively lower martian gravity prevents a stable thick atmosphere (Baker et al., 1991) and the absence of a magnetic field allows energetic solar particles to force hydrodynamic dissociation upon near-surface water molecules, releasing the heavier oxygen into the soil and allowing the lighter hydrogen to escape into the exosphere (e.g., Lundin, 2001). The released oxygen may have contributed to the oxidation of the regolith, hydrolysis of silicate minerals, and the formation of carbonate minerals. Also, impact events are believed to have contributed to atmospheric erosion or thermal escape during the period of heavy bombardment (Jakosky and Phillips, 2001).

\section{Discussion}

Contrary to the numerous works that present evidence for the possible occurrence of water bodies in the northern plains, Malin and Edgett (1999) suggest that there is insufficient Mars Orbital Camera (MOC)-based evidence to support the existence of coastlines. This apparent disagreement may be attributed to several factors, including incomplete MOC coverage of the Martian surface, inadequate testing of the features described (actually, common expressions of the shorelines associated with large terrestrial paleolakes, see Clifford and Parker, 2001), wind and water modification over a prolonged geologic time period (millions to perhaps a billion years of resurfacing), ill-defined shorelines related to rapidly diminishing water bodies shortly following inundation through the sublimation and the transferral of water into the ground and/or to freezing, the lack of an Earth-like moon to cause tidal forces responsible for the large amounts of energy available for erosion at terrestrial shorelines, or persistant environmental conditions similar to the Antarctic (Mahaney et al., 2001), which would inhibit wave activity. In this sense, searching for lines of boulders, scour marks or gravel bars, associated to the action of ice-covered oceans, might evidence Artic and Antartic-like shore morphologies (Fig. 5). Since at least the Late Noachian, no evidence of warm, but episodic milder conditions in a long-term cold and dry climate, are reported for Mars; so, morphologies and landforms related to temperate-climate shorelines, resulting from the action of waves, may be hard to found.

The inundation hypothesis is not the only hypothesis which offers explanations for some of the significant characteristics described above. An alternative mechanism for producing a dense atmosphere, for example, is the variation of Martian orbital parameters (see Carr, 1990; Touma and Wisdom, 1993; Laskar and Robutel, 1993) and related environmental/climatic changes. Touma and Wisdom (1993) proposed that an obliquity of the Martian rotation axis over 


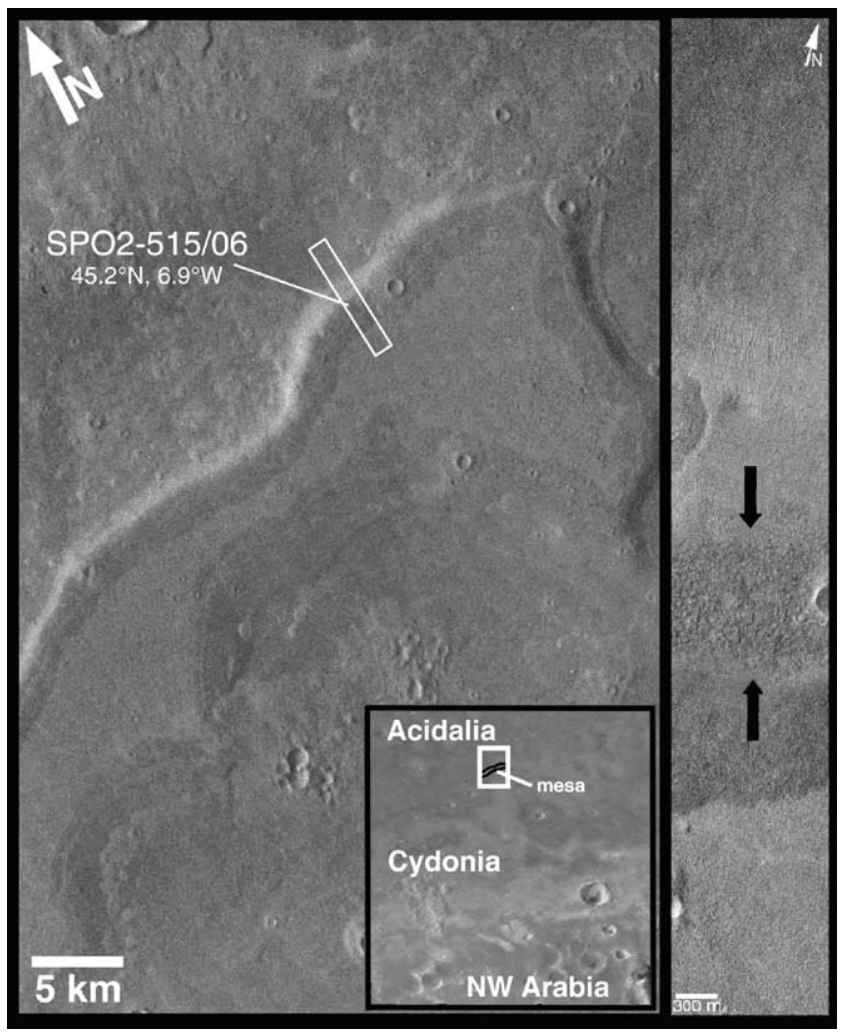

Fig. 5. 026A72 Viking image (left) and subframe of SPO2-515/06 MOC image, evidencing Artic and Antartic-like lines of boulders (indicated by arrows in the MOC image) on the Acidalia Plains $\left(45^{\circ} \mathrm{N}, 7^{\circ} \mathrm{W}\right)$ : the flat-topped mesa can so be interpreted as a possible island in a northern plains frozen ocean. (Images courtesy of MSSS.)

$30^{\circ}$ would generate an atmospheric pressure above $25 \mathrm{mbar}$, which would allow a total water release to the atmosphere equivalent to 500 pr $\mu \mathrm{m}$ (Jakosky and Carr, 1985). But this process is not necessarily different than the TMC-derived one, since it is possible that the effect of the Tharsis mass and elevation on its own could have been capable of altering martian orbital parameters (Melosh, 1980). In addition, a concurrence of Tharsis activity and a change of obliquity could have resulted in a magnified environmental/climatic change. However, it is important to note that obliquity changes have there least effect in equatorial latitudes. As such, invoking obliquity change to explain the formation of channels located near the equator and formed from catastrophic groundwater release (e.g., Mangala Valles and the surrounding groundwater sapping channels) is highly questionable (Ferris and Dohm, 2002).

In addition, liquid $\mathrm{CO}_{2}$ has been proposed to help explain the various erosional landscapes that are expressed at the martian surface, including the outflow channel systems (Hoffman, 2000). Liquid $\mathrm{CO}_{2}$, in our opinion, raises more queries than affords answers, as follows: how can a liquid $\mathrm{CO}_{2}$ reservoir persist for tens of thousands and perhaps millions of years, especially during periods of magmatic and tectonic activity, as well as impact cratering events?; how do multiple flood events occur at any one outflow channel sys- tem such as in the case of Kasei (Scott, 1993) and Mangala (Chapman and Tanaka, 1993) Valles such that there is sufficient recharge of the associated $\mathrm{CO}_{2}$ reservoirs?; how do such flows sustain their erosive capabilities for great lengths at Martian conditions? These and many other queries (e.g., Stewart and Nimmo, 2002) have yet to be addressed by the White Mars hypothesis of Hoffman (2000), though the hypothesis has provoked productive scientific debate and inquiry. $\mathrm{CO}_{2}$ as a catalyst, however, has been suspected to help trigger the large catastrophic outflows (e.g., Baker et al., 1991).

Another point of view to the concept of episodic oceans and lakes put forth in this work has recently been purported by Segura et al. (2002), who estimate that the heat generated by impacts could provide a sufficient amount of water vapor to incorporate into the atmosphere, from the conversion of shallow subsurface or polar ice and water locallyderived from the impactors themselves. As the peak in highland valley network formation is roughly coincident with the period of heavy bombardment, Segura et al. (2002) conclude that rains excavating the valley networks were triggered almost exclusively by large body impacts, a process which frequency made the persistence of temperate and wet conditions impossible. On the other hand, it has been suggested that impacts have contributed to a loss of planetary atmosphere especially during the period of heavy bombardment (Jakosky and Phillips, 2001). In addition, large impact events transfer a large amount of dust into the atmosphere. The higher the impact frequency, the more dust in the atmosphere triggering a possible chained reaction that leads to significant cooling of Mars during a time period when snowfall becomes more likely than rainfall and the formation of rivers does not occur until melt occurs and/or subglacial flows develop. Therefore, it is hard for us to reconcile the model proposed by Segura et al. (2002). Furthermore, although valley network formation may have developed as a result of large impact events, there are many other viable contributors to valley network formation and other Noachian aqueous activity (e.g., Scott et al., 1995; Tanaka et al., 1998; Craddock and Howard, 2002; Carr, 2002). The impact idea, therefore, does not invalidate the hypothesis of a great Noachian ocean: similar processes may have occurred in the terrestrial Archean oceans. Moreover, valley network formation is observed also during the Amazonian Period, although in a reduced degree (Baker et al., 1991; Scott et al., 1995); in fact, 10\% (Carr, 1995) to 40\% (Scott and Dohm, 1992) of valley networks may be younger than Noachian. Some of them are unambiguously Hesperian or Amazonian, including the valleys on the volcanoes Alba Patera, Ceraunius Tholus, and Hecates Tholus, and the tributaries incised into the walls of the central and western Valles Marineris (Carr, 2002). Thus, impact cratering during the Noachian, in our opinion, represents one of many processes that reshaped the martian landscape, and certainly does not rule out the possibility of a northern plains ocean during the 
Noachian by MEGAOUTFLO-related phenomena (Baker et al., 1991).

Clifford (1993) proposed that if the planetary inventory of outgassed $\mathrm{H}_{2} \mathrm{O}$ exceeded the pore volume of the cryosphere by more than a few percent, a subpermafrost groundwater system of global extent would necessarily result. This interconnected global aquifer would allow the downward migration of polar basal melt to result in the upward migration of water at temperate and equatorial latitude, theoretically sufficient enough to replenish regions that have lost water by magmatic and tectonic activity (including impact) and/or sublimation. Although Clifford's model can adequately explain recharge of water to Tharsis, it does not sufficiently address the surface morphology ranging from small sapping channels, mid-size valley network systems, to catastrophic outflow channel systems, which are largely concentrated in the Tharsis region. In our opinion, the inundation hypothesis best explains the diverse evidence, especially from the Late Noachian until present. Now we will discuss the inundation hypothesis.

We cannot accurately define the exact number of MEGAOUTFLO events the planet has passed through. For example, it is possible that two large-scale standing water bodies may have existed in very close periods, or perhaps even overlapping periods, allowing almost the same water amount to stand at similar topographic positions. Thus, topographic data may be inadequate to detect all possible shorelines. In consequence, this work offers a conceptual model that highlights the Tharsis-induced flood inundations in the northern plains that are recorded in the geologic history. These are the events that have appeared to have survived thousands and perhaps millions of years of wind and water erosion to stand out as significant windows of the Martian past, while smaller windows have been erased or highly subdued from the Martian record.

\subsection{The early ocean}

Long-term stability of a primordial hemispheric ocean on the lowlands of Mars has been recently argued by Clifford and Parker (2001), who established that the former presence of such an ocean can be deduced by considering the hydraulic conditions needed to explain the origin of the circumChryse outflow channels, and extrapolating them backwards in time. Furthermore, if the outflow channel flood waters were derived from a subpermafrost aquifer, as much as one third of the planet's surface would have been covered by standing bodies of water and ice throughout its first billion years of evolution. Their conclusions indicate that an ocean on Mars (as on Earth) may have condensed shortly after the planet was formed.

The total water amount on Mars' surface throughout its history remains uncertain. But, if the average depth of the Tharsis basin is between 2 and $7 \mathrm{~km}$, and its measured area is approximately $9 \times 10^{6} \mathrm{~km}^{2}$ (Dohm et al., 2001b), then the fill volume for an average depth of $5 \mathrm{~km}$ is around
$4.5 \times 10^{7} \mathrm{~km}^{3}$, much more than the equivalent to the volume of water required to create the secondary Late Hesperian ocean $\left(1.4 \times 10^{7} \mathrm{~km}^{3}\right.$, Head et al., 1999), but less than the volume required to filling the mean level of Shoreline 1 $\left(>10^{8} \mathrm{~km}^{3}\right)$. Thus, other hydrologic activities may have also contributed water to the primitive ocean, by mechanisms such as mobilization of large quantities of ground ice in the southern highlands and spring-fed activity along many areas of the highland/lowland boundary (e.g., Tanaka et al., 2002). In this sense, there is evidence of great landscape modification rates on Mars during Noachian (Phillips et al., 2001; Hynek and Phillips, 2001) and Early Hesperian (Irwin and Howard, 2002) due to the erosion by water at the surface.

There are a large number of observations that support the potential stability of this large body of water during the Noachian and possibly into the Early Hesperian, including: the higher erosion rates estimated for the lowlands (Craddock et al., 1997); the valley networks in the highlands, which major activity is documented through Noachian (e.g., Squyres and Kasting, 1994; Carr, 2002), and which typically $\mathrm{V}$ or U-shaped cross-section suggests a gradual formation process, transitioning from water-related to ice-related erosional mechanisms (Baker and Partridge, 1986); the high erosion rates during the Noachian and the extensive dissection of Noachian terrains by valley networks, comparable to terrestrial erosion rates, in a long-term fluvial activity recently suggested by Mars Odyssey-THEMIS data (Rice et al., 2003), dropping 4-6 orders of magnitude into the Hesperian and Amazonian (Golombek and Bridges, 2000), and in particular the timing of extensive denudation of the highlands, approximated to be limited to an interval of 350500 myr in the Noachian (Hynek and Phillips, 2001); or the higher early heat flow (Zuber et al., 2000), which implies that a much larger fraction of the planet's total inventory of $\mathrm{H}_{2} \mathrm{O}$ would have been present as a liquid (Clifford and Parker, 2001).

\subsection{The later ocean}

For the case of the secondary and inner ocean, Shoreline 2 represents a surface of nearly constant equipotential (Head et al., 1999), which is consistent with its interpretation as a paleoshoreline. In fact, the equipotentiallity of this Late Hesperian ocean's shoreline is only disrupted in Tharsis and Elysium, where Amazonian volcanic activity have taken place. So, Shoreline 2 should have been eroded by a fluid in hydrostatic equilibrium, and it remains almost completely equipotential, due to its relatively modern age and the presence of less energetic processes capable of deformation. Additional supporting to Shoreline 2 as an ancient shoreline are: debouching altitude of Chryse outflow channels is close to contact 2 mean level (Head et al., 1999; Ivanov and Head, 2001); surface under Shoreline 2 is smoother at all scales than that above (Head et al., 1998); the northern lowlands are covered with plains units that are mostly Late Hesperian-Early Amazonian in 
age (e.g., Scott and Tanaka, 1986; Greeley and Guest, 1987; Tanaka et al., 2002); the contact itself is close to the limits of the late Hesperian Vastitas Borealis Formation, whose sedimentary deposits strongly suggest the stability of a large body of water at the level of Shoreline 2 (Head et al., 2002) at the time of peak of outflow channel activity during the Late Hesperian (Tanaka, 1986), and which are also considered by some authors (e.g., Kreslavsky and Head, 2002) as possibly originated as a sublimation residue of a large water body; and topography of features interpreted as sub-ice volcanoes suggests an ice top in a level very close to the mean elevation of the Shoreline 2, which is consistent with a water body totally or partially frozen in the northern lowlands (Chapman, 2003). Its estimated age is $\sim 2-3$ Gyr. (Clifford and Parker, 2001), also consistent with the Late Hesperian age postulated here.

A distinct episode of outflow channel activity is documented for the Late Hesperian (Tanaka, 1986; Carr, 2002; Fig. 4), the majority concentrated on the margin of Chryse Planitia. In fact, outflow channel formation seems to have peaked at this time (Head et al., 2001; Masson et al., 2001). This and earlier outflow channel activity, especially related to the incipient development of the cirum-Chryse outflow channels, is probably driven by the continued development of Tharsis and Valles Marineris (e.g., Masursky et al., 1977; Dohm et al., 2001a), and the release of water from confined aquifers due to cracking of the cryosphere by dike injection (Wilson and Head, 2003). In addition, complex networks of drainage channels have been described in Hesperian-aged terrains (Scott et al., 1995). Therefore, the fourth great pulse (Stage 4) of Tharsis magmatic activity (Dohm et al., 2001b) probably triggered a massive regional melting of ground ice and the heating of $\mathrm{CO}_{2}$-charge groundwater that started the discharge of groundwater to the surface (Baker et al., 1991; McKenzei and Nimmo, 1999; Head and Pratt, 2001), replenishing the lowlands with a secondary and smaller ocean.

\subsection{Late Hesperian to Amazonian paleolakes}

Cabrol and Grin (1999) have catalogued 179 impact crater lakes at Viking resolution for the whole planet; in this study, a relative age was suggested for the 30 largest and these were mostly Late Hesperian to Amazonian. Cabrol and Grin (2001) proposed a method to narrow down the relative age for all of the 179 crater lakes, which includes a summary of their findings that suggests periods of warmer and wetter climatic conditions and environmental change. Also, Cabrol and Grin (2001) estimate that the main lacustrine activity is placed between 3.1 and $1.8 \mathrm{Gyr}$, and rises to a maximum in the Early Amazonian (about 2.5 to $2.1 \mathrm{Gyr}$ ). Aqueous activity continues into the Middle and Late Amazonian, though during a time when lakes appear to be less numerous. Rice (1997) presented evidence for wide age-ranging aqueous sedimentary deposits in Elysium Basin, pointing to the stability of Noachian to Amazonian lacustrine environments. Such Noachian/Hesperian- aqueous activity is also noted for Gusev impact crater basin where recurrent Ma'adim Vallis flooding may have resulted in episodic lakes (Scott et al., 1993; Cabrol et al., 1998). In addition, the presence of a significant volume of water in Utopia Basin has been proposed (Scott et al., 1995; Thomson and Head, 2001), as well as the subsurface outflow and surface runoff from the northwest flanks of the Elysium rise into the Utopia basin (Mouginis-Mark, 1985; Greeley and Guest, 1987; Skinner and Tanaka, 2001) during the Late Hesperian and Amazonian and surface runoff in north Terra Cimmeria from the Late Noachian to Early Amazonian (Nelson et al., 2001).

Scott et al. (1995) relative age-dated highland and lowland channels to determine their possible contribution to the size and stability of the paleolakes. The main suppliers of water to the lowlands were the outflow channels that emptied into Chryse Basin, and the ones that flowed into Amazonis and Elysium basins. Water and sediment volumes discharged by the Chryse outflow channels, several millions of $\mathrm{km}^{3}$ in a short period of time (Rotto and Tanaka, 1991b), might have been enough to have filled large-standing water-bodies within the basin. Floods from the Elysium channel system and the valley networks around the lowlands may have also contributed to a depositional sedimentary environment in the northern plains.

In any case, Scott et al. (1995) found that $56 \%$ of the martian channels are Noachian in age, consistent with the ideas stated here about the first great ocean. Therefore, $44 \%$ of the channels are younger than Noachian (Fig. 4); these channels are interpreted to have formed by several processes, including local hydrothermal activity due to impacts or tectonic deformation (Brakenridge et al., 1985) and magmatic activity (Baker and Partridge, 1986; Gulick and Baker, 1989; Gulick, 1998; Tanaka et al., 1998; Dohm et al., 2001a, 2001b, 2001c). Most of these channels are Late Hesperian $(31 \%)$, consistent with the emplacement epoch for the secondary ocean; but the wide range in age (Hesperian to Amazonian) of the channels that supplied the basins with water mark long periods of intermittent presence of water within the northern lowlands of Mars. In fact, valley development seems to have substantially decreased when the period of late heavy bombardment ceased, including a $\sim 2-\mathrm{km}$ decline in the mean elevation of outflow channel source regions between the Late Hesperian and Amazonian (Clifford and Parker, 2001); but it did not cease completely (Gulick and Baker, 1990), as the post-Noachian valley formation collectively point towards brief warm, wet Hesperian and Amazonian excursions from prevailing, present-day cold and dry desert conditions (Baker, 2001).

In particular, extensive flooding in the lowlands, supported by channel-meander features in many areas (Scott et al., 1995), which would have flowed over the ancient sea-floor plains are described. The channels on the lowlands were formed during the Amazonian Period, similar to those on the flanks of volcanoes in Tharsis (Gulick and Baker, 1989) or Elysium (Skinner and Tanaka, 2001), and 
in the Medusae Fossae Formation (Scott and Chapman, 1991). By this time, outflow channel activity appears to have declined and become more localized around regions of probable geothermal activity (e.g., Baker et al., 1992).

\section{Highland features}

Water-associated processes could have similarly occurred in the highlands at the same time as those in the lowlands (e.g., Baker et al., 1991; Baker, 2001; Head and Pratt, 2001). Impact cratering that resulted in the formation of large basins appears to be one of the most important processes on Mars to produce closed depressions in the cratered highlands. In some of these basins, massive accumulation of sediments have been described. For example, Gusev impact crater $\left(15^{\circ}, 184^{\circ}\right)$ is rounded by the remnants of deltaic deposits from Ma'adim Vallis (Cabrol et al., 1996), and sediments in Argyre are hundreds of meters thick and as much as kilometres thick in Hellas (Parker, 1997; Moore and Wilhelms, 2001). In addition, Cassini Crater (lat $24^{\circ} \mathrm{N}$., long $328^{\circ}$ ) shows well-defined terraces in its highly conserved rim morphology, similar to terrestrial paleoshorelines.

Basin broadening by lakeshore degradation during the late Noachian and early Hesperian has been proposed to explain these features (Parker et al., 1989). Channels of different ages are equally bordering some of these highland paleolakes in impact craters (e.g., Scott et al., 1995). So, also in the highlands, when suitable conditions may have existed on Mars perhaps related to Tharsis activity, lakes and/or ice bodies may have occupied local topographic depressions, such as in impact crater/tectonic basins.

\section{Conclusions}

The hydrogeological hypothesis presented here, consistent with available data, provides an explanation for observed geological patterns of water evolution through time on the surface of Mars, and should help to motivate further in situ investigations. The hydrological model articulated here for the water evolution on the surface of Mars is consistent with:

(1) The compelling evidence for a potentially long-lasting and great ocean covering the martian lowlands throughout the Noachian and possibly into the Early Hesperian, reaching a duration close to several hundreds of millions of years; a Late Hesperian sea extending over the deeper areas in the lowlands inset within the boundary of the first great ocean; and a number of widely distributed minor lakes, which may represent a reduced Late Hesperian sea, or ponded waters in the deeper reaches of the northern plains, related to minor Amazonian Tharsis and Elysium reduced flooding.

(2) The five specific stages of the Tharsis Superplume development, as well as possible contributions from the Ely- sium rise development during the Hesperian into the Amazonian, and their influence on the water evolution on the surface of Mars.

The model explains:

(1) Why only two coastlines can be roughly traced as complete closures of ancient oceanic basins; and the differences in equipotentiallity between them.

(2) Paleolake recurrent formation during Late Hesperian to Amazonian, even in almost contemporary times, and their wide range in level and in age.

And the model predicts:

(1) If the two Superplumes have not reached their cooling threshold, future water refilling may occur in the deeper lowlands, when they begin another stage of magmaticdriven activity.

\section{Acknowledgments}

We thank Kenneth Tanaka for the topographic map in Fig. 2, and Tayfun Oner for Fig. 3A production. Reviews by Nathalie Cabrol and James Skinner were extremely helpful in the work of this paper.

\section{References}

Acuña, M.H., Connerney, J.E.P., Ness, N.F., Lin, R.P., Mitchell, D., Carlson, C.W., McFadden, J., Anderson, K.A., Rème, H., Mazelle, C., Vignes, D., Wasilewski, P., Cloutier, P., 1999. Global distribution of crustal magnetization discovered by the Mars Global Surveyor MAG/GR experiment. Science 284, 790-793.

Acuña, M.H., Connerney, J.E.P., Wasilewski, P., Lin, R.P., Mitchell, D., Anderson, K.A., Carlson, C.W., McFadden, J., Réme, H., Mazelle, C., Vignes, D., Bauer, S.J., Cloutier, P., Ness, N.F., 2001. Magnetic field of Mars: summary of results from the aerobraking and mapping orbits. J. Geophys. Res. 106, 23403-23417.

Anderson, R.C., Dohm, J.M., Golombek, M.P., Haldemann, A.F.C., Franklin, B.J., Tanaka, K.L., Lias, J., Peer, B., 2001. Primary centers and secondary concentrations of tectonic activity through time in western hemisphere of Mars. J. Geophys. Res. 106, 20563-20585.

Baker, V.R., 1999. The MEGAOUTFLO hypothesis for long-term environmental change on Mars. Bull. Am. Astron. Soc. 31, 1133.

Baker, V.R., 2001. Water and the martian landscape. Nature 412, 228-236.

Baker, V.R., Milton, D.J., 1974. Erosion by catastrophic floods on Mars and Earth. Icarus 23, 27-41.

Baker, V.R., Partridge, J.B., 1986. Small martian valleys: pristine and degraded morphology. J. Geophys. Res. 91, 3561-3572.

Baker, V.R., Strom, R.G., Gulick, V.C., Kargel, J.S., Komatsu, G., Kale, V.S., 1991. Ancient oceans, ice sheets and the hydrological cycle on Mars. Nature 352, 589-594.

Baker, V.R., Carr, M.H., Gulick, V.C., Williams, C.R., Marley, M.S., 1992. Channels and valley networks. In: Kieffer, H.H., Jakosky, B.M., Snyder, C.W., Matthews, M.S. (Eds.), Mars. Univ. of Arizona Press, Tucson, pp. 493-522.

Baker, V.R., Strom, R.G., Dohm, J.M., Gulick, V.C., Kargel, J.S., Komatsu, G., Ori, G.G., Rice, J.W., 2000. Mars' Oceanus Borealis, ancient 
glaciers, and the MEGAOUTFLO hypothesis. In: Proc. Lunar Planet. Sci. Conf. 31st, p. 1863. Abstract [CD-ROM].

Baker, V.R., Maruyama, S., Dohm, J.M., 2002. A theory for the geological evolution of Mars and related synthesis (GEOMARS). In: Proc. Lunar Planet. Sci. Conf. 33rd, p. 1586. Abstract [CD-ROM].

Barlow, N.G., Bradley, T.L., 1990. Martian impact craters: correlations of ejecta and interior morphologies with diameter, latitude, and terrain. Icarus 87, 156-179.

Berman, D.C., Hartmann, W.K., 2002. Recent fluvial, volcanic, and tedctonic activity on the Cerberus plains of Mars. Icarus 159, 1-17.

Boynton, W., Feldman, W., Prettyman, T., Hamara, D., 2002. Subsurface ice content in the polar region of Mars: comparison between north and south. Eos Trans. AGU 83 (47). Fall Meet. Suppl., Abstract P11B-02.

Brakenridge, G.R., Newsom, H.E., Baker, V.R., 1985. Ancient hot springs on Mars: origin and paleoenvironmental significance of small martian valleys. Geology 13, 859-862.

Burr, D.M., Grier, J.A., McEwen, A.S., Keszthely, L.P., 2002a. Repeated aqueous flooding from Cerberus Fossae: evidence for very recently extant, deep groundwater in Mars. Icarus 159, 53-73.

Burr, D.M., McEwen, A.S., Sakimoto, S.E., 2002b. Recent aqueous floods from the Cerberus Fossae, Mars. Geophys. Res. Lett. 29. 10.1029/2001GL013345.

Cabrol, N.A., Grin, E.A., 1999. Distribution, classification and ages of martian impact crater lakes. Icarus 142, 160-172.

Cabrol, N.A., Grin, E.A., 2001. The evolution of lacustrine environments on Mars: is Mars only hydrologically dormant? Icarus 149, 291-328.

Cabrol, N.A., Grin, E.A., Dawidowicz, G., 1996. Ma'adim Vallis revisited through new topographic data: evidence for an ancient intravalley lake. Icarus $123,269-284$.

Cabrol, N.A., Grin, E.A., Landheim, R., 1998. Ma'adim Vallis evolution: geometry and models of discharge rate. Icarus 132, 362-377.

Cabrol, N.A., Wynn-Williams, D.D., Crawford, D.A., Grin, E.A., 2001a. Recent aqueous environments in martian impact craters: an astrobiological perspective. Icarus 154, 98-113.

Cabrol, N.A., Grin, E.A., Dohm, J.M., 2001b. From gullies to glaciers: a continuum of evidence supporting a recent climate change on Mars. EOS Trans. AGU 82 (47). Abstract F694.

Cabrol, N.A., Wynn-Williams, D.D., Crawford, D.A., Grin, E.A., 2001c. Recent aqueous environments in impact craters and the astrobiological exploration of Mars. In: Proc. Lunar Planet. Sci. Conf. 32nd, p. 1255. Abstract [CD-ROM].

Carr, M.H., 1990. D/H on Mars: The effect of floods, volcanism, impacts and polar processes. Icarus 87, 210-227.

Carr, M.H., 1995. The martian drainage system and the origin of valley networks and fretted channels. J. Geophys. Res. 100, 7478-7507.

Carr, M.H., 1996a. Water on Mars. Oxford Univ. Press, New York.

Carr, M.H., 1996b. Channels and valleys on Mars: cold climate features formed as a result of a thickening cryosphere. Planet. Space Sci. 44, $1411-1423$.

Carr, M.H., 2002. Elevations of water-worn features on Mars: implications for circulation of groundwater. J. Geophys. Res. 107, 5131. 10.1029/2002JE001845.

Chapman, M.G., 1994. Evidence, age, and thickness of a frozen paleolake in Utopia Planitia, Mars. Icarus 109, 393-406.

Chapman, M.G., 2003. Sub-ice volcanoes and ancient oceans/lakes: a martian challenge. Global Planet. Change 35, 185-198.

Chapman, C.R., Jones, K.L., 1977. Cratering and obliteration history of Mars. Ann. Rev. Earth Planet. Sci. 5, 515-540.

Chapman, M.G., Tanaka, K.L., 1993. Geologic map of the MTM-05152 and -10152 quadrangles, Mangala Valles region of Mars. USGS Misc. Inv. Ser. Map I-2294 (1:500,000).

Chapman, M.G., Tanaka, K.L., 1996. Geologic maps of the MTM 25062 quadrangle (digital compilation) and the MTM 25067 quadrangle (manual compilation), Kasei Valles region of Mars. USGS Misc. Inv. Ser. Map I-2398 (1:500,000).

Chapman, M.G., Masursky, H., Scott, D.H., 1991. Geologic map of science study area 2, north Kasei Valles, Mars (MTM 25072 quadrangle). USGS Misc. Inv. Ser. Map I-2107 (1:500,000).
Clifford, S.M., 1993. A model for the hydrologic and climate behaviour of water on Mars. J. Geophys. Res. 98, 10973-11016.

Clifford, S.M., Parker, T.J., 2001. The evolution of the martian hydrosphere: implications for the fate of a primordial ocean and the current state of the northern plains. Icarus 154, 40-79.

Craddock, R.A., Maxwell, T.A., 1993. Geomorphic evolution of the martian highlands through ancient fluvial processes. J. Geophys. Res. 98, 34533468 .

Craddock, R.A., Greeley, R., 1994. Geologic map of the MTM-20147 quadrangle, Mangala Valles region of Mars. USGS Misc. Inv. Ser. Map I-2310 $(1: 500,000)$

Craddock, R.A., Howard, A.D., 2002. The case for rainfall on a warm, wet early Mars. J. Geophys. Res. 107. 10.1029/2001JE001505.

Craddock, R.A., Maxwell, T.A., Howard, A.D., 1997. Crater morphometry and modification in the Sinus Sabaeus and Margaritifer Sinus regions of Mars. J. Geophys. Res. 102, 13321-13340.

DeHon, R.A., 1992. Geologic map of the Pompeii quadrangle (MTM 20057), Maja Valles region of Mars. USGS Misc. Inv. Ser. Map I-2203 $(1: 500,000)$.

DeHon, R.A., Pani, E.A., 1992. Duration and rates of discharge through a martian outflow system: Maja Valles. In: Proc. Lunar Planet. Sci. Conf. 23rd, pp. 297-298. Abstract [CD-ROM].

Dohm, J.M., Tanaka, K.L., 1999. Geology of the Thaumasia region, Mars: plateau development, valley origins, and magmatic evolution. Planet. Space Sci. 47, 411-431.

Dohm, J.M., Anderson, R.C., Baker, V.R., Ferris, J.C., Hare, T.M., Strom, R.G., Rudd, L.P., Rice, J.W., Casavant, R.R., Scott, D.H., 2000. System of gigantic valleys northwest of Tharsis Montes, Mars: latent catastrophic flooding, northwest watershed, and implications for northern plains ocean. Geophys. Res. Lett. 27 (21), 3559-3562.

Dohm, J.M., Anderson, R.C., Baker, V.R., Ferris, J.C., Rudd, L.P., Hare, T.M., Rice Jr., J.W., Casavant, R.R., Strom, R.G., Zimbelman, J.R., Scott, D.H., 2001a. Latent outflow activity for western Tharsis, Mars: significant flood record exposed. J. Geophys. Res. 106, 12301-12314.

Dohm, J.M., Ferris, J.C., Baker, V.R., Anderson, R.C., Hare, T.M., Strom, R.G., Barlow, N.G., Tanaka, K.L., Klemaszewski, J.E., Scott, D.H., 2001b. Ancient drainage basin of the Tharsis region, Mars: Potential source for outflow channel systems and putative oceans or paleolakes. J. Geophys. Res. 106, 32943-32958.

Dohm, J.M., Tanaka, K.L., Hare, T.M., 2001c. Geologic, paleotectonic, and paleoerosional maps of the Thaumasia region of Mars. USGS Misc. Inv. Ser. Map I-2650, scale 1:5,000,000.

Dohm, J.M., Maruyama, S., Baker, V.R., Anderson, R.C., Ferris, J.C., Hare, T.M., 2002. Plate tectonism on early Mars: diverse geological and geophysical evidence. In: Proc. Lunar Planet. Sci. Conf. 33rd, p. 1639. Abstract [CD-ROM].

Edgett, K.S., Parker, T.J., 1997. Water on early Mars: possible subaqueous sedimentary deposits covering ancient cratered terrain in western Arabia and Sinus Meridiani. Geophys. Res. Lett. 24, 2897-2900.

Fairén, A.G., Ruiz, J., Anguita, F., 2002. An origin for the linear magnetic anomalies on Mars through accretion of terranes: implications for dynamo timing. Icarus $160,220-223$.

Ferris, J.C., Dohm, J.M., 2002. Comparative Hydrogeomorphology of Wet Beaver Creek, Arizona, and Abus Vallis, Mars. Icarus. Submitted.

Frey, H.V., 2003. Large-diameter visible and buried impact basins on Mars: implications for age of the highlands and (buried) lowlands and turnoff of the global magnetic field. In: Proc. Lunar Planet. Sci. Conf. 34th, p. 1838. Abstract [CD-ROM].

Frey, H.V., Roark, J.H., Shockey, K.M., Frey, E.L., Sakimoto, S.H., 2002. Ancient lowlands on Mars. Geophys. Res. Lett. 29. 10.1029/2001GLO13832.

Golombek, M.P., Bridges, N.T., 2000. Erosion rates on Mars and implications for climate change: constraints from the Pathfinder landing site. J. Geophys. Res. 105, 1841-1853.

Greeley, R., Guest, J.E., 1987. Geologic map of the eastern equatorial region of Mars. USGS Misc. Inv. Ser. Map I-1802B (1:15,000,000).

Gulick, V.C., 1998. Magmatic intrusions and hydrothermal origin for fluvial valleys on Mars. J. Geophys. Res. 103, 19365-19387. 
Gulick, V.C., Baker, V.R., 1989. Fluvial valleys and martian palaeoclimates. Nature 341, 514-516.

Gulick, V.C., Baker, V.R., 1990. Origin and evolution of valleys on martian volcanoes. J. Geophys. Res. 95, 14325-14334.

Hartmann, W.K., Neukum, G., 2001. Cratering chronology and the evolution of Mars. Space Sci. Rev. 96, 165-194.

Head, J.W., 2002. The hydrological cycle in the last $80 \%$ of Mars history: sources, locations, residence times, stability, duration and evolution of $\mathrm{H}_{2}$ O. In: Proc. Lunar Planet. Sci. Conf. 33rd, p. 1724. Abstract [CDROM].

Head, J.W., Pratt, S., 2001. Extensive Hesperian-aged south polar ice sheet on Mars: evidence for massive melting and retreat, and lateral flow and ponding of meltwater. J. Geophys. Res. 106, 12275-12299.

Head, J.W., Kreslavsky, M., Hiesinger, H., Ivanov, M.A., Pratt, S., Seibert, N., Smith, D.E., Zuber, M.T., 1998. Oceans in the past history of Mars: test for their presence using Mars Orbiter Laser Altimeter (MOLA) data. Geophys. Res. Lett. 25, 4401-4404.

Head, J.W., Hiesinger, H., Ivanov, M.A., Kreslavsky, M.A., Pratt, S., Thomson, B.J., 1999. Possible ancient oceans on Mars: evidence from Mars Orbiter Laser Altimeter data. Science 286, 2134-2137.

Head, J.W., Greeley, R., Golombek, M.P., Hartmann, W.K., Hauer, E., Jaumann, R., Masson, P., Neukum, G., Nyquist, L.E., Carr, M.H., 2001. Geological processes and evolution. Space Sci. Rev. 96, 263-292.

Head, J.W., Kreslavsky, M.A., Pratt, S., 2002. Northern lowlands on Mars: evidence for widespread volcanic flooding and tectonic deformation in the Hesperian period. J. Geophys. Res. 107. 10.1029/2000JE01445.

Hess, P.C., Parmentier, E.M., 2001. Implications of magma ocean cumulate overturn on Mars. In: Proc. Lunar Planet. Sci. Conf. 32nd, p. 1319. Abstract [CD-ROM].

Hoffman, N., 2000. White Mars: a new model for Mars' surface and atmosphere based on $\mathrm{CO}_{2}$. Icarus 146 (2), 326-342.

Hynek, B.M., Phillips, R.J., 2001. Evidence for extensive denudation of the martian highlands. Geology 29, 407-410.

Irwin III, R.P., Howard, A.D., 2002. Drainage basin evolution in Noachian Terra Cimmeria, Mars. J. Geophys. Res. 107. 10.1029/2001JE001818.

Ivanov, M.A., Head, J.W., 2001. Chryse Planitia, Mars: topographic configuration, outflow channel continuity and sequence, and tests for hypothesized ancient bodies of water using Mars Orbiter Laser Altimeter (MOLA) data. J. Geophys. Res. 106, 3275-3295.

Jakosky, B.M., Carr, M.H., 1985. Possible precipitation of ice at low latitudes of Mars. Nature 315, 559-561.

Jakosky, B.M., Phillips, R.J., 2001. Mars' volatile and climate history. Nature 412, 237-244.

Janhunen, P., 2002. Are the northern plains of Mars a frozen ocean? J. Geophys. Res. 107. 10.1029/2000JE001478.

Jöns, H.P., 1986. Arcuate ground undulations, gelifluxion-like features and "front tori" in the northern lowlands on Mars. What do they indicate? In: Proc. Lunar Planet. Sci. Conf. 17th, pp. 404-405. Abstract [CD-ROM].

Kargel, J.S., Strom, R.G., 1992. Ancient glaciation on Mars. Geology 20, 3-7.

Kargel, J.S., Baker, V.R., Beget, J.E., Lockwood, J.F., Pewe, T.L., Shaw, J.S., Strom, R.G., 1995. Evidence of ancient continental glaciation in the martian northern plains. J. Geophys. Res. 100, 5351-5368.

Komatsu, G., Kargel, J.S., Baker, V.R., Strom, R.G., Ori, G.G., Mosangini, C., Tanaka, K.L., 2000. A chaotic terrain formation hypothesis: explosive outgas and outflow by dissociation of clathrate on Mars. In: Proc. Lunar Planet. Sci. Conf. 31st, p. 1434. Abstract [CD-ROM].

Kreslavsky, M.A., Head, J.W., 2002. Fate of outflow channel effluents in the northern lowlands of Mars: the Vastitas Borealis Formation as a sublimation residue from frozen ponded bodies of water. J. Geophys. Res. 107 (E12), 5121. 10.1029/2001JE001831.

Lachenbruch, A.H., Morgan, P., 1990. Continental extension, magmatism and elevation; formal relations and rules of thumb. Tectonophysics 174, $39-62$.

Laskar, J., Robutel, P., 1993. The chaotic obliquity of the planets. Nature 361, 608-612.

Lucchitta, B.K., 1981. Mars and Earth: comparison of cold-climate features. Icarus 45, 264-303.
Lucchitta, B.K., 1982. Ice sculpture in the martian outflow channels. J. Geophys. Res. 87, 9951-9973.

Lucchitta, B.K., Ferguson, H.M., Summers, C., 1986. Sedimentary deposits in the northern lowland plains, Mars. J. Geophys. Res. 91, E166-E174.

Lundin, R., 2001. Erosion by the solar wind. Science 291, 1909-1910.

Mahaney, W.C., Dohm, J.M., Baker, V.R., Newsom, H.E., Malloch, D., Hancock, R.G.V., Campbell, I., Sheppard, D., Milner, M.W., 2001. Morphogenesis of Antarctic paleosols: martian analog. Icarus 154, 113-130.

Malin, M.C., Edgett, K.S., 1999. Oceans or seas in the martian northern lowlands: high resolution imaging tests of proposed coastlines. Geophys. Res. Lett. 26, 3049-3052.

Malin, M.C., Edgett, K.S., 2000a. Sedimentary rocks of early Mars. Science 290, 1927-1937.

Malin, M.C., Edgett, K.S., 2000b. Evidence for recent groundwater seepage and surface runoff on Mars. Science 288, 2330-2335.

Mars Channel Working Group, 1983. Channels and valleys on Mars. Geol. Soc. Am. Bull. 94, 1035-1054.

Masson, P., Carr, M.H., Costard, F., Greeley, R., Hauber, E., Jaumann, R., 2001. Geomorphologic evidence for liquid water. Space Sci. Rev. 96, $333-364$.

Masursky, H., Boyce, J.M., Dial, A.L., Schaber, G.G., Strobell, M.E., 1977. Classification and time of formation of martian channels based on Viking data. J. Geophys. Res. 82, 4016-4038.

McGill, G.E., 1985. Age and origin of large martian polygons. In: Proc. Lunar Planet. Sci. Conf. 16th, pp. 534-535. Abstract [CD-ROM].

McKenzei, D., Nimmo, F., 1999. The generation of martian floods by the melting of ground ice above dykes. Nature 397, 231-233.

McSween Jr., H.Y., Murchie, S.L., Crisp, J.A., Bridges, N.T., Anderson, R.C., Bell III, J.F., Britt, D.T., Brückner, J., Dreibus, G., Economou, T., Ghosh, A., Golombeck, M.P., Greenwood, J.P., Johnson, J.R., Moore, H.J., Morris, R.V., Parker, T.J., Rieder, R., Singer, R., Wänke, H., 1999. Chemical, multispectral, and textural constrainst on the composition and origin of rocks at the Mars Pathfinder landing site. J. Geophys. Res. 104, 8679-8715.

Melosh, H.J., 1980. Tectonic patterns on a reoriented planet: Mars. Icarus 44, 745-751.

Milton, D.J., 1974. Geologic map of the Lunae Palus quadrangle of Mars. USGS Misc. Inv. Ser. Map I-894 (1:5,000,000).

Moore, J.M., Wilhelms, D.E., 2001. Hellas as a possible site of ancient icecovered lakes on Mars. Icarus 154, 258-276.

Mouginis-Mark, P.J., 1985. Volcano/ground ice interactions in Elysium Planitia, Mars. Icarus 64, 265-284.

Nelson, D.M., Greeley, R., 1999. Geology of Xanthe Terra outflow channels and the Mars Pathfinder landing site. J. Geophys. Res. 104, 8653-8669.

Nelson, D.M., Farmer, J.D., Greeley, R., 2001. Hydrologic history of south Elysium basin—north Terra Cimmeria area, Mars. In: Proc. Lunar Planet. Sci. Conf. 32nd, p. 2069. Abstract [CD-ROM].

Parker, T.J., 1997. Fluvial and lacustrine degradation of large martian basins during the Noachian. Workshop on Early Mars: Geologic and Hydrologic Evolution, Physical and Chemical Environments, and the Implications for Life, Houston, TX. Abstract 3073.

Parker, T.J., Schneeberger, D.M., Pieri, D.C., Saunders, R.S., 1987. Geomorphic evidence for ancient seas on Mars. In: MECA Symposium on Mars: Evolution of its Climate and Atmosphere, LPI Tech. Rept. 87-01, Lunar and Planet. Inst., Houston, TX, pp. 96-98.

Parker, T.J., Saunders, R.S., Schneeberger, D.M., 1989. Transitional morphology in the west Deuteronilus Mensae region of Mars: implications for modification of the lowland/upland boundary. Icarus 82, 111-145.

Parker, T.J., Gorsline, D.S., Saunders, R.S., Pieri, D.C., Schneeberger, D.M., 1993. Coastal geomorphology of the martian northern plains. J. Geophys. Res. 98, 11061-11078.

Phillips, R.J., Zuber, M.T., Solomon, S.C., Golombek, M.P., Jakosky, B.M., Banerdt, W.B., Smith, D.E., Williams, R.M.E., Hynek, B.M., Aharonson, O., Hauck, S.A., 2001. Ancient geodynamics and global-scale hydrology on Mars. Science 291, 2587-2591.

Pounders, E., Anderson, R.C., Dohm, J.M., Haldemann, A.F.C., Golombek, M.P., 2002. Tectonic evolution of the eastern hemisphere of Mars. In: Proc. Lunar Planet. Sci. Conf. 33rd, p. 1906. Abstract [CD-ROM]. 
Rice, J.W., 1997. Elysium basin, Mars: An intermittent or perennial lake from Noachian to Amazonian time. Workshop on Early Mars: Geologic and Hydrologic Evolution, Physical and Chemical Environments, and the Implications for Life, Houston, TX. Abstract 3052.

Rice Jr., J.R., DeHon, R.A., 1996. Geologic map of the Darvel Quadrangle (MTM 20052), Maja Valles region of Mars. USGS Misc. Inv. Ser. Map I-2432 (1:500,000).

Rice, J.W., Christensen, P.R., Ruff, S.W., Harris, J.C., 2003. Martian fluvial landforms: a THEMIS perspective after one year at Mars. In: Proc. Lunar Planet. Sci. Conf. 34th, p. 2091. Abstract [CD-ROM].

Rotto, S.L., Tanaka, K.L., 1991a. Geologic history and channeling episodes of the Chryse Planitia region of Mars. In: Proc. Lunar Planet. Sci. Conf. 22nd, pp. 1135-1136. Abstract [CD-ROM].

Rotto, S.L., Tanaka, K.L., 1991b. Chryse Planitia region, Mars: channeling history, flood-volume estimates, and scenarios for bodies of water in the northern plains. Mars Surface and Atmosphere through Time Workshop, Boulder, CO, LPI Technical Memo 92-01, 111-112.

Rotto, S.L., Tanaka, K.L., 1995. Geologic/geomorphologic map of the Chryse Planitia region of Mars. USGS Misc. Inv. Ser. Map I-2441.

Ruiz, J., Fairén, A.G., de Pablo, M.A., 2003. Thermal isostasy on Mars. In: Proc. Lunar Planet. Sci. Conf. 34th, p. 1090. Abstract [CD-ROM].

Schubert, G., Solomon, S.C., Turcotte, D.L., Drake, M.J., Sleep, N.H., 1992. Origin and thermal evolution of Mars. In: Kieffer, H.H., Jakosky, B.M., Snyder, C.W., Matthews, M.S. (Eds.), Mars. Univ. of Arizona Press, Tucson, pp. 147-183.

Scott, D.H., 1993. Geologic map of the MTM 25057 and 25052 quadrangles, Kasei Valles region of Mars. USGS Misc. Inv. Ser. I-Map 2208 $(1: 500,000)$

Scott, D.H., Chapman, M.G., 1991. Mars Elysium basin: geologic/volumetric analyses of a young lake and exobiologic implications. In: Proc. Lunar Planet. Sci. Conf. 22nd, pp. 669-677. Abstract [CDROM].

Scott, D.H., Chapman, M.G., 1995. Geologic and topographic maps of the Elysium Paleolake Basin, Mars. USGS Misc. Inv. Ser. Map I-2397 $(1: 5,000,000)$.

Scott, D.H., Dohm, J.M., 1992. Mars highland channels: an age assessment. In: Proc. Lunar Planet. Sci. Conf. 23rd, pp. 1251-1252. Abstract [CDROM].

Scott, D.H., Tanaka, K.L., 1986. Geologic map of the western equatorial region of Mars. USGS Misc. Inv. Ser. Map I-1802-A (1:15,000,000).

Scott, D.H., Chapman, M.G., Rice, J.W., Dohm, J.M., 1991a. New evidence of lacustrine basins on Mars: Amazonis and Utopia Planitiae. In: Proc. Lunar Planet. Sci. Conf. 22nd, pp. 53-62. Abstract [CD-ROM].

Scott, D.H., Rice, M.G., Dohm, J.M., 1991b. Martian paleolakes and waterways: exobiological implications. Orig. Life Evol. Bios. 21, 189-198.

Scott, D.H., Dohm, J.M., Applebee, D.J., 1993. Geologic map of science study area 8, Apollinaris Patera region of Mars. USGS Misc. Inv. Ser. MAP I-2351.

Scott, D.H., Dohm, J.M., Rice, J.W., 1995. Map of Mars showing channels and possible paleolake basins. USGS Misc. Inv. Ser. MAP I-2461.

Segura, T.L., Toon, O.B., Colaprete, A., Zahnle, K., 2002. Environmental effects of large impacts on Mars. Science 298, 1977-1980.

Skinner, J.A., Tanaka, K.L., 2001. Long-lived hydrovolcanism of Elysium. Eos. Trans. AGU 82 (47), Fall Meet. Suppl. Abstract P31B-07.

Sleep, N.H., 1994. Martian plate tectonics. J. Geophys. Res. 99, 5639-5655.

Smith, D., Zuber, M.T., 1996. The shape of Mars and the topographic signature of the hemispheric dichotomy. Science 271, 184-188.

Squyres, S.W., 1979. The distribution of lobate debris aprons and similar flows on Mars. J. Geophys. Res. 84, 8087-8096.
Squyres, S.W., 1989. Water on Mars. Icarus 79, 229-288.

Squyres, S.W., Kasting, J.F., 1994. Early Mars: how warm and how wet? Science 265, 744-749.

Squyres, S.W., Clifford, S.M., Kuzmin, R.O., Zimbelman, J.R., Costard, F.M., 1992. Ice in the martian regolith. In: Kieffer, H.H., Jakosky, B.M., Snyder, C.W., Matthews, M.S. (Eds.), Mars. Univ. of Arizona Press, Tucson, pp. 523-554.

Stewart, S.T., Nimmo, F., 2002. Surface runoff features on Mars: testing the carbon dioxide formation hypothesis. J. Geophys. Res. 107. 10.1029/2000JE001465.

Tanaka, K.L., 1986. The stratigraphy of Mars. J. Geophys. Res. 91, 139158.

Tanaka, K.L., 1997. Sedimentary history and mass flow structures of Chryse and Acidalia Planitiae, Mars. J. Geophys. Res. 102, 4131-4150.

Tanaka, K.L., Banerdt, W.B., 2000. The interior lowland plans unit of Mars: evidence for a possible mud ocean and induced tectonic deformation. In: Proc. Lunar Planet. Sci. Conf. 31st, p. 2041. Abstract [CD-ROM].

Tanaka, K.L., Scott, D.H., Greeley, R., 1992. Global stratigraphy. In: Kieffer, H.H., Jakosky, B.M., Snyder, C.W., Matthews, M.S. (Eds.), Mars. Univ. of Arizona Press, Tucson, pp. 345-382.

Tanaka, K.L., Dohm, J.M., Lias, J.H., Hare, T.M., 1998. Erosional valleys in the Thaumasia region of Mars: hydrothermal and seismic origins. J. Geophys. Res. 103, 31407-31419.

Tanaka, K.L., Skinner, J.A., Hare, T.M., Joyal, T., Wenker, A., 2002. Resurfacing history of the northern plains of Mars based on geologic mapping of Mars Global Surveyor data. J. Geophys. Res., Planets, Special Edition. In press.

Thomson, B.J., Head, J.W., 2001. Utopia Basin, Mars: characterization of topography and morphology and assessment of the origin and evolution of basin internal structure. J. Geophys. Res. 106, 23209-23230.

Touma, J., Wisdom, J., 1993. The chaotic obliquity of Mars. Science 259, 1294-1296.

Turcotte, D.L., Scherbakov, R., Malamud, B.D., Kucinskas, A.B., 2002. Is the martian crust also the martian elastic lithosphere? J. Geophys. Res. 107. 10.1029/2001JE001594.

Wilhelms, D.E., Squyres, S.W., 1984. The Martian hemispheric dichotomy may be due to a giant impact. Nature 309, 138-140.

Wilson, L., Head, J.W., 2003. Oceans in the northern lowlands of Mars? Assessment of dike emplacement as a mechanism for rapid release of a confined subcryosphere aquifer. In: Proc. Lunar Planet. Sci. Conf. 34th, p. 1186. Abstract [CD-ROM].

Wise, D.U., Golombek, M.P., McGill, G.E., 1979. Tectonic evolution of Mars. J. Geophys. Res. 84, 7934-7939.

Wyatt, M.B., McSween, H.Y., 2002. Spectral evidence for weathered basalt as an alternative to andesite in the northern lowlands of Mars. Nature 417, 263-266.

Zimbelman, J.R., Craddock, R.A., Greeley, R., 1994. Geologic map of the MTM - 15147 quadrangle, Mangala Valles region of Mars. USGS Misc. Inv. Ser. Map I-2402 (1:500,000).

Zuber, M.T., 2001. The crust and mantle of Mars. Nature 412, 220-227.

Zuber, M.T., Solomon, S.C., Phillips, R.J., Smith, D.E., Tyler, G.L., Aharonson, O., Balmino, G., Banerdt, W.B., Head, J.W., Johnson, C.L., Lemoine, F.G., McGovern, P.J., Neumann, G.A., Rowlands, D.D., Zhong, S., 2000. Internal structure and early thermal evolution of Mars from Mars Global Surveyor topography and gravity. Science 287, 17881793. 